International Journal of Social Research
(ISSN:2576-5531)

\title{
Women With Regenerative Potential As Against Women With Destructive Potential (The Case Study Of Amma Darko's "Faceless")
}

\section{Georgina Brookman-Andoh1, Philomena Okyeso Abaka ${ }^{2}$, Martin Gyekye Ampofo ${ }^{3}$}

${ }^{1}$ Faculty 1 St. louis College of Education, Department of Languages, 2Department of English, KN-

UST; ${ }^{3}$ Faculty of Education,KNUST.

\section{ABSTRACT}

The research looked at the woman with regenerative potentials and how reliable mentors they are to the benefit of society using Ama Darko's Faceless. The purpose of the study was to use Ama Darko's Faceless to showcase the position of the woman with regenerative potential irrespective education because though Education empowers women to have regenerative potentials other women who are uneducated also exhibit such traits in our societies. A qualitative approach was employed to look at views related to the African woman with regenerative potential and also adopted the traditional library research approach through the use of books, articles, journals and publications in as much as they contribute to the worth of the study. It was informed by the stiwanist theory. The main findings of the study indicate that the woes of irresponsible mothers who do not responsibly take care of the results of their pleasure with men are being disapproved. This disapproval is as a result of the pitiful portrayal of women with destructive potential as against positive up lifting portrayal of women with regenerative potential and making them reliable mentors of society. This change has come about as a result of women's quest to assert themselves through education and contribute towards freeing their families from cultural and societal dogmas in which women were treated to subjugation and marginalization. A remarkable observation was the intentionality of ascribing to female characters more respectable roles in novels by various writers as the years go by. A conclusion drawn from the study is that education is still a major weapon of enhancing assertiveness in women but it is not the ultimate.

Keywords: Regenerative potential, destructive potential, the woman with regenerative potential, the woman with destructive potential, Education and stiwanism.
*Correspondence to Author: Georgina Brookman-Andoh

St. louis College of Education, Department of Languages

How to cite this article:

Georgina Brookman-Andoh, Philomena Okyeso Abaka, Martin Gyekye Ampofo. Women With Regenerative Potential As Against Women With Destructive Potential (The Case Study Of Amma Darko's “Faceless"). International Journal of Social Research, 2021; 5:53.

\section{eScîPub}

eSciPub LLC, Houston, TX USA. Website: https://escipub.com/ 


\section{INTRODUCTION}

This paper discusses the technique used by Ama Darko's faceless and it contributes to the discourse of the role education plays in the empowerment of women. Three main characters are discussed; Maa Tsuru, who is not educated and not assertive in any means, NaaYomo who is not educated but very assertive, who stands for the traditional responsible woman who took care of the coming generation and Kabria who is educated and stands out to be the narrators mouthpiece of educating the society on the benefits derived from the activities of an assertive woman. It is explained clearly from the narrative that both women with destructive potentials and those with regenerative potentials. Interestingly, as the story unfolds, the women with regenerative potentials eclipse those with destructive potentials and the result is that the narrator showcases the assertive woman or the woman with regenerative potentials-making them reliable mentors to the benefit of women.

\section{Theory}

Stiwanism is a word coined by Molara OgundipeLeslie in 1994. Ogundipe-Leslie (2007, p. $550)^{53}$, explains that she names herself a Stiwanist to pinpoint her position within feminisms, which she defines as "A cluster of ideologies or as movements for gender equity and democracy" She continues that as African women, "We need always to speak of feminisms rather than feminism since there are so many perspectives and differing social needs that we need to articulate and address."

Ogundipe Lesley defines "Stiwa" as an acronym that stands for Social Transformation Including Women in Africa. This ideology describes the role of African women without necessarily making them imitate or define African women's agenda on their continent in relation to other feminisms, such as white Euro-American feminisms. With "STIWA" Ogundipe-Leslie (2007) exposes the needs of African women in relation to their indigenous cultures. Stiwanism concerns primarily the contemporary social and political transformation of African women in Africa. Ogundipe-Leslie (2007) explains that "what African women want is a social transformation and not necessarily rivaling men or reversal of gender roles." African women desire a peaceful society where both sexes have a social responsibility in transforming the livelihood of the entire African society. It seems that some African women scholars, perceive the word 'feminism' as rather too powerful and threatening such that the word lacks the genuineness of an indigenous African tradition. This situation therefore explains the angst behind the devising of new templates fitted to the concerns of recent writings by African women writers. It could be considered that this relatively new directions in recent writings had helped critics to advocate and formulate ideologies that synthesize an African theory which locates their own experiences. In other words, African female writers seem to have a desire to define themselves properly without being limited by what they are thinking and by being focused on their area of concern, socially and geographically.

The study concurs mainly with this prolific and bold theory of Social Transformation including Women in Africa "STIWANISM" and supports the fact that though the African woman is still predominantly portrayed as a victim in various ways, she must be cautious in identifying totally with feminism. This is because the African woman's position is peculiar and requires a line of action tailor-made to cater for her social empowerment and liberation. Already it has been realized that the factors that influence the position of African woman in gender discourse are linked to the African cultural stipulations and expectations. These factors are so burdensome that it demands a liberated psyche such that there must be a deeper probing of the issues being raised concerning the relevance of feminism to the African educated woman living in Africa. 
Maa Tsuru, a mother of six children including Fofo and Baby T, embodies the over burdening of womanhood in the patriarchal society shown in Amma darko's Faceless. Tsuru's character explains the presentation of a woman with destructive potentials. She is presented with anger, pity and as a disappointment to womanhood.

Maa Tsuru's extended family home was a house of many faces. And Odarley, there as, so to say, John the Baptist, took in all the hawk- like eyes that stole suspicious stares at her, she ventured past the door of the first of the twelve rooms. That door and that of the second room were both shut. In front of the third, a girl of about eight was fanning a charcoal pot fire. Odarley greeted the girl's mother who was washing clothes in an aluminium basin, The woman didn't respond. Odarley greeted again and louder, again the woman didn't respond. There was no way she could not have heard the second greeting.

"Mama," the eight year old girl called her mother, "she was greeting you," and pointed at Odarley.

The woman glared at her daughter. "Did I tell you I was deaf?" She roared. The girl recoiled. "Dare to imply that again and see how your cheeks will burn under the heat of my palms like the fire you are lighting."...

"All because of one greeting?" Odarley was baffled. The woman knew her. That was obvious. And knew she was there to see Maa Tsuru. The woman's behaviour therefore, could only mean one thing: that she was at loggerheads with MaaTsuru. Who else was and why?

"John the Baptist" is written to have symbolic and allegorical interpretations. On the literal level, John the Baptist is about a person who is sent as a forerunner to testify about the truth to people and usher them into repentance from sin and turn back to God. He himself was not the truth; he came only as a witness to the truth. (John 1:7\&8) Throughout his preaching he makes people aware that he is not the truth but has come to pave way for the truth so that through him all might believe. However, the use of this word has a deeper or suggestive meaning of suspicion and anger. Interestingly, John does not live among the people he preaches to and Odarley who is called as John the Baptist does not also live among the people. John lives in the desert and Odarley lives in the streets. As John the Baptist speaks against the sins of the world and has come to reveal a greater news to the world and this news is not to benefit him alone so as Odarley comes to pave the way for a greater news that will not benefit her friend Fofo alone but will benefit all the children in the streets as well as all mothers who are not responsibly taking care of the results of their pleasure with men. Just as the Pharisees asked questions about who john is, based on their suspicion, Odarley receives suspicious stares from the compound where Maa Tsuru resides. Here, there is an extended metaphor "hawk-like eyes" which could be explained as investigating eyes. This imagery is used here to interpret the anger expressed by the people in the house who see no important personality in MaaTsuru nor her Fofo nor her other children. Therefore, to receive a forerunner before Fofo to give a message to the "nonentity" MaaTuru leaves a fruit for thought. It is significant to note that John the Baptist received suspicious glares from the Pharisees who were then controlling affairs. The fact is that they could not decipher who he really was because they did not see any clear interpretation from him about his personality. 
This sometimes caused their anger for him. In the same way, the anger for Odarley explained that there was no clear understanding in having her as a forerunner to a person who is considered to be one of those people who are seen as nonentities. The effect of using this imagery is to emphasize the writer's displeasure about all those children brought into the world by MaaTsuru in the process of satisfying her sexual desires and also to disapprove of irresponsible behaviour. This kind of irresponsible behaviour is usually perceived wrongly from the biblical interpretation according to First Peter chapter three verse seven that the woman is the weaker sex. However this same Christian principles contradict itself when in First Corinthians chapter one verse twenty seven and twenty eight, there is another interpretation that God chooses the weakest through whom to make his strength manifest. A lot of women ignore the later and allow the first interpretation to make their lives so miserable because that is what society dictates. An example of this situation is presented through MaaTsuru when she is portrayed with pity.

"Maa Tsuru, Fofo's mother was leaning by her charred doorsill, her blank eyes, staring into nothingness, did not notice Odarley enter the compound house." The persona's choice of words as used in this quotation, portrays properly and perfectly the subject matter considered here as in pity used for womanhood. Ironically, although the diction is not difficult, it expresses a difficult situation. Words such as leaning, blank, charred, nothingness as used in this short sentence presented here indicate a life full of pity, looking at their meanings in modern usage. The phrase, "leaning by her charred doorsil," expresses a life of dependency on nothing. If one depends on nothing, then it means literally as a life that is lonely and so helpless. And such a life situation is very difficult. To lean means to stand against something instead of being upright. Charred also means blank and burnt. Therefore, to depend on something that is blank and burnt explains how helpless such a life has become. It is only a woman without a mind of her own that will not stand upright and face life as it is but rather depend on nothing and live a miserable life because she is the weaker sex. The use of blank eye by the narrator can be extended to mean that Maa Tsuru did not have foresight and thus cannot see harm when it is approaching. The narrator continues that she did not notice Odarley coming and this could mean metaphorically that since she is not educated and is not endowed with the foresight to perceive a problem, she could not perceive all the troubles approaching and she placed herself into a difficult situation that affected society. This could be explicated through MaaTsuru's manner of producing children:

Maa Tsuru's second pregnancy marred her already soured relationship with her aunt. She found herself more and more dependent on Kwei. It was tough for him but with the arrival of their second son, Kwei's heart melted and his determination to care for them all doubled. For a while, it appeared that everything would be fine. Then the unexpected happened...Maa Tsuru was still spending the nights with Kwei. Neither of them took any precaution. They knew it could happen. They assumed and hoped it wouldn't. Then it did. Maa Tsuru became pregnant the third time, while their second son was still crawling. Kwei became a changed man overnight. "How?" he yelled at Maa Tsuru. "Why? Why did you let it happen? As though he played no part at all in the making of it. p120

It is clear that MaaTsuru is not critical about her plight before doing anything and this does not make her assertive. She has limited her understanding to the conscience of society (that she is a woman (the weaker sex) and needs to 
depend on a man for her survival) Therefore without a man in her life, she is nothing as she is presented in the novel. Meanwhile, her encounter with Kwei opens up the woes of her life. Because MaaTsuru is not analytic, she could not see reason with her Auntie when she demanded that Kwei comes forward to pay her bride price but she kept on sleeping with him without protection knowing very well that she could be pregnant again. This whole scenario shows irresponsibility on the side of MaaTsuru for at least, she should have had to agree with her auntie to build some dignity around her character by allowing herself to get married before taking the role of a wife. The narrator here skillfully portrays the plight of women and young girls in a merciless world dominated by greedy, irresponsible and often cruel men in their livee. Kwei is an example of an irresponsible father. His major interest is in producing children and not consciously taking care of their upbringing. He leaves Maa Tsuru with the responsibility of taking care of their four children all by herself. Even when Maa Tsuru is pregnant with his third child, Kwei goes for a different woman. The absence of a father in her home and the burden of taking care of four children all by herself, without any meaningful income, makes Maa Tsuru, as portrayed by the omniscient narrator in the novel, a willing target of poverty. Though the so called curse is presented to be the cause of MaaTsuru's sense of irresponsibility, poverty could also be explained to be partly the cause of her irresponsible nature towards her children. Poverty is said to be the cause of a lot of ills in society. According Jonathan Alter (1994), sited in a New York Times Headline (12/12/94), "poverty is a public enemy number one." It could be argued that no group is guilty of irresponsible attitude in the current climate than unmarried teenage mothers with no meaningful income. Naa Yomo is used to debunk the assertion by using the mind to deal with a matter of this sort when she explains that she and her husband gives water to their children and encourages them to stay in times like this but it is not all heads that can have the advantage of reasoning this way. Besides, fate, by means of supporting superstition as in the curse placed upon Maatsuru,s head as emphasized in the novel, it becomes difficult for her to be a responsible parent. By her actions and inactions, she pushes her children into the jaws of the street. Fofo's determination to irk out in the street proves right the argument that MaaTsuru is herself a causal agent of streetism.

The entire three hundred and sixty-five days of the previous year Fofo had visited the house not more than twice, even though her abode at Sodom and Gomorrah was only some few kilometers away. The current year was already into its fifth month, and, but for the nightmare with Poison, she still would not have been calling. Her emotions about the woman who had carried her for nine full months in the womb confused her sometimes. Deep down inside her, she felt some affection for Maa Tsuru. Yet an overpowering urge to hate her also consumed her sometimes. She often pondered over whether what she deemed to be hatred was merely a desire to cushion the pain of her existence and to blame Maa Tsuru whom she held responsible for dumping her in the world, because that was how she felt about herself, dumped. p20.

The narrator explains the plight of Fofo and remains indifferent here. To probe deeper into the situation, Fofo's feelings as presented here adds to MaaTsuru's sense of irresponsibility. For a child of this age to express this feeling of pain and confusion brings to the fore that the mother of such a child is not rational. Though MaaTsuru in a way, could be sympathized with, there is the understanding that one's lifestyle and one's future lies in one's own hands. How 
that life is led sometimes determines a dark or bright future. If MaaTsuru had thought about the consequence of sleeping with a man regardless of the consequence, then she need not receive sympathy. Naa Yomo was not presented rich nor educated in the narrative yet she behaves rationally. Fofo's emotions about MaaTsuru as presented here encompass contrary impressions or ideas. The image of contradiction (oxymoron) is reflected in this extract. Two contrasting words (affection and hatred) are used at the same time. The effect of using this sense device is to advocate the fact that being a woman does not give one the impetus to be weak-that women must desist from seeing themselves in that way because though women are perceived to be the weaker vessel, some of these so called weaker vessels have been able to strengthen themselves to be relevant to society. The greatest strength of the gospel according to the Christian perspective, hangs on the resurrection. If not, why in heavens name did Jesus Christ reveal himself first to a woman to testify? Showing weakness does not show assertiveness. MaaTsuru's depiction does not show assertiveness. Because she is not assertive, she is easily deceived. Kwei, an unemployed mason impregnates her once and continues to do so until she is pregnant with her fouth child. On each occasion of her pregnancy, Kwei runs away only to come and succeeds in impregnating her again. When Kwei leaves her permanently, Nii Kpakpo also comes up with a lie that he works for a big company in Tema, This turns out to be false, yet, Maa Tsuru continues to stay with him until she has two children with him. She does not seem to think critically about issues before making a choice. The gullibility of Maa Tsuru partly leads to the tragic rape of Baby $\mathrm{T}$.

Maa Tsuru landed one look upon her face and knew that something was wrong. Fofo stared at her and said slowly, "The thing coming out of Baby T's there is not blood, mother." Maa Tsuru's brow furrowed. Were her daughters up to some trick? Did they think they would get away with it? She wrenched one Charlie wotee from one foot, held it at a ready to strike in the right hand and thumped her way towards the back of the house. She caught sight of Baby $\mathrm{T}$, approached her, laid a good look upon her and knew instantly that all was not well with her... What is that at the back of your ...."and blinked, cutting herself short suddenly as the nature of the stain behind Baby T's dress hit her full in the face. She realized her mistake...disgusted with herself, and helped Baby T up. Baby T was in obvious pain. Maa Tsuru held her by the waist and made Baby $T$ place her one arm over her shoulder for support because she was limping. They treaded their way slowly to the house and into the room, Maa Tsuru laid Baby $T$ down on her mat and made her to spread her legs. She gasped at what she saw. She should as a matter of fact have asked Baby $T$ who did it to her. Somehow she couldn't bring herself to. She was afraid that the answer would turn out to be the suspicion brewing inside her head. In which case, would the blame not also be equally on her head too? What had she done first time when he used only his fingers on her? She began to clean Baby $T$ with a warm towel and wept silently as she did. They were tears for herself more than for Baby $T$.

The attitude of the narrator is disappointing. MaaTsuru's attitude in dealing with this problem of rape supports the issue of disappointment. 
Though she sensed that her daughter has been maltreated, she could not bring herself to do anything than take money as bribe to cover up such an atrocious act. Because she does not have an analytic mind, she does not subject her mind to analysis before taking the decision of exchanging justice with money. Her lack of confidence and the fear of losing a man pushes her into shelving a freedom that could have helped her to speak out and be heard. In breath-taking situations of this sort, an educated woman can move out of poverty in order to break herself from the grip of nothingness and helplessness. Situating this issue to how Kabria helped in making somebody out of Fofo, a mere street child she wouldn't have allowed such a nice case that could aids somebody's justice to be shelved. This depiction of the woman as a nonentity, with neither ambition nor concrete abilities has really been the thrust of the force that motivated African women writers to correct the atrociously misconceived and misrepresented African woman. It is not out of place therefore that Ama Darko consciously recreates the authentic African woman who knows her mind and with the strength of education which according to Gerda Learna $(1997)^{5}$ "is the purveyor of knowledge and truth," performed nurturing roles, have their ambitions and contributes to the dynamics of economics in the micro and macro systems." In line with her expectations, Amma Darko presents female characters like Naa Yomo and Kabria who irrespective of their challenges are able to carve admirable identities for themselves and their children.

Naa Yomo is the eighty four year old woman who lives in the same house with MaaTsuru in Accra. There is no clear reference in the text about Naa Yomo's educational background but her ability to decipher right from wrong though there is no proper education mentioned in connection to her character is what is useful to the study. What makes her character significant to this study is how her assertiveness contributes to society: She tells Vickie and Kabria about her ability to ensure the proper upbringing and prosperity of her children in addition to her pride for her family home that she refuses to be relocated by her prosperous children and even the government.

"Oh no! They have all moved out. They are all in good employment. Three of them even work in other regions. Those who are here live in fine bungalows. They wanted to move me from here. Can you believe that?

"You didn't want to go and live in the bungalow?" Vickie feigned interest.

"Move from here?" Naa Yomo screeched. "Here where I survived the great earth quake of 1939 ?

"You were in this house during the great earth earthquake?" Kabria grew interested.

"Where else could I have been? From the time I could bath myself, I have lived in this house.

Part of this house was leveled to the ground, but we stayed on. When they were resettling others at Korle-Gonno and Kaneshie and Abossey-Okai, we refused to move. We rebuilt this house with our sweat and toil. This house was built on a foundation of honour. Now see what some of them have done to this honour." And pointed her walking stick at Maa Tsuru's door.

It could be argued that on the literal surface this conversation considers the manner of living in that part of Accra and how people still cherish to remain there though the place is not conducive for habitation and the government has also issued a law for evacuation. However it could be extended to explain the concept, feminism and the fight for gender equality so far. The situation here supports the view that feminism existed in Africa since 1939 and Yaa Yomo seems to 
represent the strong, jubilant and assertive woman who contributed proudly to the honour of motherhood. Significantly Naa Yomo represents wisdom and a good sense of pride in parenting. Upon meeting Vickie and Kabria, her initial questions to them is " do you have children?" On knowing that Kabria has three and Vickie has none she tells them that she has had eleven out of which five are dead. As a proud parent, Naa Yomo together with her husband took good care of the remaining six children. Because of this all her six living children are gainfully employed in different parts of the country. Her pride as a parent contrast sharply with Maa Tsuru who shirk her duty as a mother. Naa Yomo Praises her husband's support to her during their time of parenting. With this, her definition of " a good man is apt. For Naa Yomo, a good man will never send his children to the streets because there is no money. Rather " a good man" will give his children a lot of water to drink and comfort them that he would provide them with their needs the next day. We glean from Naa Yomo's exemplary definition that poverty should not be used as an excuse for throwing one's children onto the streets. Though her mind is not schooled she she has the ability to analyze issues and decide what is acceptable. Here is the analytic mind in action, which makes NaaYomo assertive. Being assertive, Naa Yomo's answer to Vikie's question as to why she (Naa Yomo) will not move to join her children in fine bungalows also attest to the fact that she is content. She used a question as an answer to Vickie's question "Move from here?" The pitch of voice used in the asking of this question is described as "screeched." To screech, according to the Macmillan English Dictionary for Advance Learners; International Student Edition(2002), means, to make a loud, unpleasant noise, especially when one is upset. Presenting her in this manner explains how she cannot just be controlled any how because she knows her right and knows what is good for her. By her use of this pitch, we understand how reluctant she is to move locations. Naa Yomo is a woman who does not make rush judgments. For instance, her decision to stay in the old compound house was arrived at very careful thought. A careless reader will accuse her of being conservative but that is not the case. Naa Yomo's determination to stay in that house reveals her attachment to the history of her forebears.

"Do you know that this house stands on the original settlement of our forefathers when they came in from Niger country?" Naa Yomo circumvented Kabria's question.

"Really?" Vickie played along.

"Yes," Naa Yomo felt encouraged.

"This very spot here, where this stool of mine sits, is proper Accra. Did you know that? And somewhere beneath this earth is my umbilical cord. The first two teeth in my mouth grew here. The last two would come off here. That was what I told my children."

The stool is a traditional symbol that marks one's authority in the traditional society. It is appropriately personified to effect the kind of authority associated with stools. Also, stools occupy particular spaces. Thus Naa Yomo's insistence on a clearly defined space for the stool also establishes the kind of authority she exerts in that family. Being the only old woman and the authentic representative of her lineage, she makes sure she upholds not only tradition but her right of place among her people. She is therefore the right person to ensure sanity among the other members of the generation to come after her and this includes the behavior of MaaTsuru that seems to wash away the honour obtained so far. In support of this very analogy, the stiwanist posits that the African woman needs to focus on a social transformation of a positive nature in Africa where positive means being concerned with everything that maximizes the quality of life and life's potential. In other words being a woman only demands the use of the mind to identify how being a woman can Https://escipub.com/international-journal-of-social-research/ 
enable her to contribute meaningfully to the society where she belongs. The emphases is on the relationship between the environment and the human being. Naa Yomo's clever approach to Kabria's question described as circumvented also reveals her tact at handling questions. By volunteering information about her ancestry, Naa Yomo was eager to instill in these young women the need to connect with their roots. The earth and its inhabitants have a kind of relationship and there is the need for preservation. This is even stated as: "We rebuilt this house with our sweat and toil. This house was built on a foundation of honour. Now see what some of them have done to this honour." And pointed her walking stick at Maa Tsuru's door." There is the use of another sense device, synecdoche. Sweat and toil as used here represents hardwork. Naa Yomo, went through hard times to take care of her children's upbringing without pushing them into the streets though she was not presented as one who has money or education. To be able to bring up children to become responsible adults and not a burden to society is not an easy task. It involves a high sense of emotional pressure. It is when one is able to go through this hard work that one can proudly talk about the success of her children. It is the assertive mind that will be able to endure this. The manner how NaaYomo is presented in the narrative, reveals the assertive mind in action. The assertive mind speaks with courage and with precision. Whatever Naa Yomo says comes out with confidence and because of her character as an old woman she is pictured to be informed thus her confidence draws attention to herself and this shows assertiveness. In a chat with the ladies from MUTE, NaaYomo analyses the effect of a curse on one who believes in its efficacy. The crisp analysis reveals her assertive nature.

It is the curse," Naa Yomo said and drifted off again. "I have seen the making of babies here, their deliveries, their growth. I have observed transactions, good and bad. I can recite to you the causes of many fights and quarrels in this house. I can attest to marriages, the proper ones and the co-habitations. This house was built by an honourable man for his twelve sons. I am the daughter of one of those twelve sons. I am the only direct grandchild of the great man still alive in this house. Everyone else here is either a great or great-great or great-great-great or great- great-great-great grandchild or grand niece and grandnephew of the honourable man. I have lived through the making and painful breaking up of families in this house. I have born witness to mothers who cane their children into the classroom and mothers who cane their children out of the classroom and onto the streets. Thirty-eight years ago, she was born in the very room inside which she has now locked herself

According to the narrator, Naa Yomo represents the fact that old folks are custodians of African history. NaaYomo gives a suitable background to MaaTsuru's association with "the curse" She reveals that Maa Tsuru is a product of a curse and tells that before her birth her father refused responsibility of her as his daughter. This brings shame to Tsuru's mother who therefore hated the man who impregnated her and thus curses him and all his generation. This to an extent is the reason why, perhaps things do not go well for MaaTsuru and her offspring. From Naa Yomo's analyses, the word "transactions" is metaphorically used to emphasize the business of marriage and relationships especially that which is found in Naa Yomo's explanation of transaction. She explains marriage as a kind of business deal. Just as in a business, marriage takes in income, pays expenses and aims to have little profit left. Like a small business, your relationship has one or more sources of income, it has expenses, and, like a business, marriage is suppose to make profit-to create savings, investment and equity. (Things that would call asset). Ideally, You have money left over in the 
bank at the end of the month. As partness in a marriasge you have similar financial responsibilities to partners in a business. In fact some businesses are called partnerships. Family members are somewhat like employees. They do maintenance chores and homework and receive deligation of tasks from mum and dad and are the chief operating and financial officers and their tasks is to figure out how to locate the funds coming in as well as how to provide the necessary guidance and services to their staff (children) and to each others. In business, there is a lot of discussions about cooperate culture. That is the attitude and practices within the business. How employees and executives deal with each other, the ethics of the company and their focus in meeting goals and becoming successful. Likewise, your marriage must have a family culture. How you interact as partners and family members, your mutual goals, and how successful and unsuccessful you are in meeting those goals. NaaYomo tries to liken what has existed before in that family house to what MaaTsuru is experiencing in her relationship and showcases hers as unwanted and disgraceful to the honour obtained so far.

She also proudly tells of her family history right from the Gold Coast or pre-independence era. Naa Yomo also informs Vickie and Kabria of her grandfather and great grandfather's direct dealings with the white colonialists. When they left they both agree that Naa Yomo possesses enormous knowledge that Kabria admits that if the content of her head could be deciphered "she could fill up another George padmore Library." The narrator uses hyperbolic analyses here since the analogy is too sweet to be true but there is a purpose for this exaggeration. In fact it is to emphasize that the old woman is so much informed that she served as a gold mine to the members of MUTE during their investigations about Fofo's and her ultimate triumph. If the mind that has not under gone formal education could be used in this way, then the educated mind will do it even better. Kabria who is educated as presented in the text is given as evidence to this fact.

Kabria is a wife and mother of three who works with MUTE, a nongovernmental organization that is basically into documentation and information build up. Kabria is presented as an assertive woman in Faceless who is also faced with the issue of patriarchy Just as MaaTsuru. Unlike MaaTsuru, Kabria, the mother, wife, worker and a battered car owner, could negotiate life in such a way that she is able to execute all the demands imposed on her as a woman. she could do this with the help of her education.

The mother, wife, worker and a batteredcar owner that she was, no day passed that Kabria didn't wonder how come the good Lord created a day to be made up of only twenty four hours, because from dawn to dusk, domestic schedules gobbled her up; office duties ate her alive; her three children devoured her with their sometimes realistic and many times unrealistic demands; while the icing on the cake, their father, needed do no more than simply be her regular husband, and she was in a perpetual quandary.

The form of this complex sentence in the above extract agrees with its content. There are about thirteen punctuation marks contained in this single sentence. Out of these thirteen punctuation marks, seven of them are commas that are used in sentences to indicate pauses. To pause for seven time in one sentence can be used to emphasize how burdensome Kabria's problem was to her.. The use of a lot of phrases and clauses all contained in one sentence also expresses how complex the issue of womanhood can be explained and to indicate the process of her mind. Kabria accepts that the burden of womanhood weighs her down but she considered thinking about a way out. The narrator uses "perpetual quandary" to emphasize and to symbolize the process of her mind in deciding the best way of going about her problem as a career woman and this she could 
do because she was educated. This extract gives a graphic description of Kabria's lifestyle. It could be realized that there is so much demand on her as a mother.

The narrator uses the word gobble about Kabria's domestic duties and this describes how unpleasant her situation is when she has to take care of her domestic duties. As a mother, she is suppose to wake up at dawn and still goes to bed at dusk. She is the one who sees to it that her children are also awake and do not make unnecessary noise to disturb her husband in the morning whilst taking care of their morning chores like cleaning around and preparing themselves for school. Kabria makes sure that she endures her children's stubbornness and carefree attitude as well as solve the petty squabbles that usually occurs in the mornings among her children (which could break nerves sometimes) in order not to make Adade, her husband angry. She also makes sure that breakfast is served and the whole family eat together. She is again suppose to prepare her children's lunch boxes. Upon all these that she does in the morning before going to work she still has to drop her children at school and pick them up after school. These children who are mothered in this way are described by the narrator as so selfish that they are said to devour Kabria with their sometimes realistic and many times unrealistic demands. From the extract, the word devour connotes complete destruction. This is because the children have been metaphorically used in place of a lion. It is also the lion and some other dangerous animals that can devour or destroy completely. The situation has been exaggerated as well and the hyperbolic instance is to effect the fact that her children did not consider the plight of their mother and selfishly demanded so much from her. For example, Ottu, who did not know what Kabria was going through after seeing a pamphlet that teaches about sexual health under the pillow of her fifteen year old daughter, has to demand selfishly that he feels hot inside the packed car and that she should hurry and drive the car because they are going to be late for school. He did not think about the problem he made her go through that very morning before he was able to make himself ready for leaving. Obea also approached her after she successfully dropped them at school and when they got out from the car for her to drive away, her car could no more move since it developed a hitch. Obea and Esi cried to their mother for embarrassing them because her car misbehaved in front of their friends. They did not think about the fact that she had sacrificed to bring them to school and that she needed to be at her office in time and was to use that car which cannot move. Instead, Essie asked her unrealistically that she must buy a new car.

Kabria as a worker went through so much. The narrator explains that her job at MUTE was flexible and enabled to be there for the children. There was also a relaxed and an informal atmosphere that suited her fine but she couldn't eat her cake and have it. Though the job could't pay much, It entailed sometimes going out into the field to research and talk to people for information and verification. It is also explained by the narrator that she mostly needed to sit behind her working table to sift and sort out information and data. She is the one to write reports for their documentation centre which Diana fondly refers to as The alternative Library. Apart from this schedules her Boss usually sends her to the market to shop for her and if she needs to go and come back fast she needed to use her creamy that mostly gives her hell. Compounding this hell of problems, she goes back to pick her children from school after the hard days work.

As a wife, she was to see to the needs of her regular husband Adade who remained a typical patriarchal man who does not see why he should support his wife in any of her duties. The narrator uses the icing on the cake to symbolize the sweet and beautiful moments that marriage must possess. However, inside of the wedding cake, is very dark with some parts, sour in taste. Kabria rather experiences the dark side of 
marriage life which makes her burden enormous. To elaborate on this fact, Though Kabria was always up with the crows, Adade wakes up at six am; an hour after his wife has, reads the news papers and spends a lot of time in the bathroom and still be the first person to leave the house, leaving Kabria to take the children to and from school in her rickety car after the hard work done in the morning and at work as well as make sure diner is ready to meet Adade's request of always coming home to meet his food ready. All that Adade does is to provide his children with shelter and finance. Kabria goes through emotional and psychological upbringing of his children alone. On the basis of Ms. Kamame's classification of fathers, Adade falls under the group of fathers with narrow perception of fatherhood; who sees his role fulfilled so long as he has paid the school fees, placed food on the table and puts clothes on the child's back. (p108). It is because he over burdens his wife that she proposes that a law be enacted or made by the government to compel husbands to support their wives at home just as it has been done at Cuba.

As a battered car-owner, creamy kept on hitting Kabria hard severally and caused her to be desperate and infuriated almost every day in her life. As an instance, her children became angry and attacked her for disgracing them in front of their school when she thought she was showing motherly love by not making them join a trotro vehicle to school as some children do. To emphasize on how hurt Kabria is when this incident happened, The narrator uses figurative imagery to expand sensory perception beyond the literal meaning. The choice under the types is the simile ,"It squealed like a mouse in a strangler's grip." We are aware of how breaks or tyres of cars can squeal on the streets which are usually normal. However, the writer goes further and introduces another sensory detail-the sound of a mouse in a stranglers grip. It gives pleasure or surprise to the imagination. In the example above, we never connected a mouse in a stranglers grip to the sound or noise made by the break or tyres of a car. The choice of this imagery seems to replicate in words the depth of the humiliation the whole situation can cause its owner. From the graphic description of Kabria's lifestyle one would agree that she is hemmed in by all these demands that she dares questions the creator for allowing only twenty hours to make up a day. Adade could have lessened her burden by helping out in the house or even taking on the duty of sending the children to school and picking them up after school. Upon all these Kabra strengthens herself with the help of her education. Education enables Kabria to understand and appreciate the needs and sensibilities of her fifteen year old daughter.

Obea, her first child, at fifteen, had reached, so to say, that age three years after her grand entry into the teen world, three more to qualifying to vote. And as much as Kabria could recall, Obea said goodnight to her one night, baby faced, flat chested and all, only to wake up the following morning sporting a blossoming bosom and a pair fairly rounded hips. The result? Obea threw both Kabria and Adade into absolute turmoil. There she was, one minute their little girl, next moment protesting any reference to her as their little girl. And while Kabria suffered her period of discomfort in silence, praying to God for guidance on how to deal with her now physically maturing daughter, Adade, for his part, retired to bed each night wondering if the time had not come for him to maybe invest in two bulldogs to discourage potential young male whistlers behind the wall

It is true that to train up a child is not easy but an educated person can have the advantage of making it possible to have a civilized home full of civilized children. It is only the brain that can 
engage in a comparative kind of analysis as exemplified by Kabria's own analysis of Obea's rather early entry into adolescence that can seek appropriate means of shaping the current life of her child. From the extract, there is the use of hyperbole in the sense that the narrator exaggerates about Obea changing within twenty four hours from a child to a description that shows the characteristics of an adult. We believe that this cannot be possible but it is to effect the fact that their daughter's situation threw both parents into a very difficult situation describe by the narrator as "perpetual turmoil." The significant aspect about the situation is how the two of them approached the issue. The narrator recounts that Kabria suffered her period of discomfort in silence praying to God for guidance while Adade is also described to invest in two bulldogs to discourage potential young male whistlers. The mind of the assertive woman is showcased here. It is only the assertive mind that understand that it is not every issue that one' $\mathrm{s}$ ability can perform. In other words the assertive mind leaves those issues that she is not capable of dealing with, and allows the one with expertise in that field to work. Because Kabria is educated she could do this even better. She was able to understand that issues of this sort demands divine intervention and therefore decided to seek God for solution. This is the assertive mind in action. Adade on the other hand could not think critically about this before he decided to buy two bulldogs to discourage potential young male whistlers behind the wall. The question is, can those bulldogs follow Obea any where she goes including going to school? This question debunks the idea that women are the weaker sex. It is significant to note that a lot of people use the bible as the basis for speaking about this fact. However, This same bible speaks strongly about equality of the gender. (Psalm 139: 14). From A Pre-Marriage Counseling Handbook, written by Allan \& Donna Goerz (2007), they talk about the gender complementarily. They assert that "Complementarily, while men like to hide from their emotional ramifications (run from their feeling), women are more consistent in willing to let their thought be connected to their emotions." In fact women find the greatest bridge between the head and the heart. This is strongly showcased through Kabria. It has been said in the discussion so far that Kabria has been the one who is always interested in the children's emotional and psychological needs. How she does this so well is because she is educated and assertive. It is this quality she possesses that enables her to cope with her unfeeling husband who is always indifferent about her plight and only considers his feelings alone without caring about the fact that his wife will need his help and support in the house. Kabria receives this behavior of her husband with wisdom though she is sometimes frustrated a lot. The narrator recounts that:

Adade who always rose from bed each working day at 6 a.m., never one minute earlier which was a whole hour after Kabria. His expectation to find his breakfast table laid, ready and wait after he had hijacked the bathroom for thirty minutes and used another fifteen minutes to dress up, was always met religiously by Kabria. He never came to the breakfast table without a newspaper in his hand. To Adade, that would be akin to wearing shoes without socks. So that, sometimes, he would rather re-read a newspaper he had already read, than not read at table at all. His motto was that old news was better than no news. And if his head was buried in a newspaper, and Kabria asked a question, all she got was a nod or shake of the head for an answer. Sometimes stubbornness and frustration pushed her on to persist till she got him to open his mouth but the often brief and snappy 
reply was always never worth the energy she invested in her persistence. p14

The narrative voice uses Adade's character to showcase how patriarchy is entrenched on the African soil. It explains how the man is pictured to be the subject and the woman is humiliated under this subject. It is very painful to speak and seek response that never comes. What makes the situation more painful is to seek this from a very special person like a husband. It is interesting to note that, after working tirelessly for this fellow to feel comfortable and the reward for this hard work is a response that the narrator agrees is never worth the energy invested in her persistent could be very burdensome for Kabria to handle. However it is emphasized that she met all these religiously. On the literal surface, she tries to put herself within the confines of a wife which has been an accepted norm that the wife must submit to the husband no matter the situation. However, because Kabria is assertive and educated, she finds a way out of making Adade's means of frustrating her not become something that can weigh her down. The word religiously as used here is metaphorically chosen to effect the fact that there are many routes leading to the same goal, to use the words of Molara Ogundipe Lesley in her essay about Stiwanism. From the essay, there are different forms of feminism and all those forms that there are depends on the geographical location. Therefore, in order not to be imitative and still satisfy ones goal of asserting ones right, ones geographical location must be a great factor in determining ones worth as a woman. For Kabria's life to be meaningful to her as a woman she is suppose to craftily manage her cohabitation with her husband. The narrator emphasizes Kabria's means of dealing with feminism in the character of Creamy. Kabria's car:

Finally, creamy. The car had been in and out of every kind of workshop from Abeka to Zongo so many times and undergone all kinds of clinical and plastic surgeries, that it seemed to have grown immune to both. Creamy was a name that Kabria held so dear to heart that she once shocked Adade with the extent of her passion when he dared to put it to the test. p15

Symbolically, Creamy represent this burden of womanhood that Kabria tries to manage in the patriarchal society as found in Faceless. For emphasis on the problem of womanhood, Creamy is characterized in a proper noun to picture how huge this problem that has no name is affecting womanhood. For it to be personified, gives the evidence of how burdensome Kabria's life is affected in the patriarchal situation found in faceless. From the extract, Creamy has been a problem for Kabria to solve almost every day. It is showcased in how it has undergone all kinds of plastic surgeries that seemed to have grown immune to. The fact that Kabria continues with this act of servicing the car is her continuous management of her home inspite of the problems she is faced with. The strength to overcome all these problems without much complains shows how assertive she is and this could also be obtained through education. The narrator uses the situation of Creamy and Kabria to effect the fact that women under the grip of patriarchy will definitely find problems, even very huge ones but they need to gather strength to overcome. It is worthy of note that the omniscient narrator categorically uses education as this strength that women need to overcome this burden of patriarchal strings holding and pulling women from achieving self realization. Kabria is used in an argument with her husband Adade in the novel to emphasize the issue of education as the strength that women need:

It was after one of Creamy's many plastic surgeries, which left it so tattooed that it required urgent re-spraying. Unable to squeeze anything out of her meager salary, she sought help from Adade. 
'Don't you receive a salary?' Adade asked.

'Don't get sarcastic with me,' Kabria retorted. 'If I had had the time to study further as you did, I would also have been reaping the benefits today in terms of a better salary. But I was busy making babies then. Remember?

It was a line of argument that Adade always tried to avoid.

'Okay,' he said simply to shut her up,p15

The narrator discusses the fact that education makes a woman economically empowered that she becomes independent in satisfying her own needs and also aids her ability to assert her rights over issues. It could be obtained from the extract that though Kabria could not obtain much education due to the burden of womanhood, her little knowledge acquired from the little time available to her helped her to use her brain when Adade tried to swerve her about the issue of helping her to repair her car:

But come the subsequent first day and second day and third day; and neither word nor assistance came. Kabria cast her mind onto the daily bottles of beers quaffed in the name of releasing tension and paid Adade a surprise visit at his fine office the fourth day.

Tu-tu-tu-tu-tu... Creamy's furious engine and exhaust heralded its tattooed arrival. And Kabria, who meant business, parked it right beside Adade's brand new Toyota Corolla, provided him on loan by his employers. When Adade saw his wife and her car, he prayed desperately for the earth to open up and swallow him whole. Kabria compounded his embarrassment by deliberately soliciting for more attention with her loud and gay hellos to all of Adade's co-workers; then in their full and attentive glare, hopped gingerly into the car and drove away in the same tu-tu-tu-tutu fashion. Her little coup d'etat paid off. Adade came home that night with the required car paint.

The above information explains how important the issue of education can make a woman so assertive that in a mild and crafty way, Kabria finds a way through a demand that could have caused a serious fight between a husband and a wife. Meanwhile, Kabria hides her anger under the exhibits of Creamy, her car, that cannot be questioned and dealt with because it is not human but can be used for this purpose because it has been assigned human exhibits that presents the idea of the burden of womanhood and how to fight it back. Creamy is used to showcase Kabria's anger and this is captured through the sentence ; "Creamy's furious engine and exhaust heralded its tattooed arrival." The sound of the engine, and the body of the car as expressed in the word "tattoo" explains it all. The narrative voice presents this through a comic relief to humorously to interject into the painful presentation of Kabria's plight in order to relieve readers of the tension in the narrative. The fact about putting her thoughts together and designing such an idea to force her way through her demand presents how assertive she is and also expresses the educated mind in action. The issue of being assertive is extended through how she insists on the colour cream when Adade tried being the man that he is and decided to buy blue paint, the colour of his taste in order to change the cream colour and give it the colour he feels is good for the car but Kabria insisted on her cream colour when she questioned:

"Is it cream?" Kabria asked.

Adade gave her a look to kill.

"What colour is it?" She pressed.

"Blue!" he snapped.

"Blue?" She roared.

"Yes. Metallic sea blue!

"What kind of bits-and-pieces colour is that? She wailed. 
Adade flared up, utterly flabbergasted. "Bits and pieces of a colour?

"Yes, "Kabria howled. "How do I call my Creamy, Creamy, after it has been sprayed this metallic sea blue?

Adade was so shocked that he didn't know what to say. He was so furious that when he attempted to speak, it came out a wheeze. He returned the paint the following day, declined the offer to exchange it at a little inconvenience cost for a cream colour, and told Kabria bluntly that for all he cared, she could call at his office ten thousand times a day with her tattooed tu-tu-tu-tu Creamy.

After three weeks he gave in to her stubbornness and determination to drive Creamy in its tattooed state rather than have it sprayed any other colour than cream.p15

It could be argued that Kabria's assertive nature enabled her to insist on maintaining the name of Creamy. This situation confirms the fact that though being a woman is burdensome, there is no way of changing from being a woman into a man or swerving the character of a woman with her responsibility and what make a woman a woman and still be a woman. The woman only needs to liberate her psyche in order to achieve self realization through how she handles matters of womanhood. This situation is captured in the "WH" interrogative clause, "What kind of bitsand-pieces colour is that..." and the narrator continues to show how complex it will be when the woman refuses being a woman and adopts another way of life that is not suitable on the African soil using this complex sentence, "How can I call my Creamy,Creamy after it has been sprayed this metallic sea blue?" This confirms the study's focus on Stiwanism and supports Molara Ogundipe's assertion that she identifies with feminisms and not feminism. This she says to explain the fact that as concerned African women we need to focus on our social and geographical environment and think about a critical transformation of a positive meaning with everything done that maximizes the quality of life of the African woman. The narrative voice endorses this behaviour when she presents Kabria to exhibit this character of being capable of combining marriage life, mothering, working and still work out ways of co existing effectively as in the instance of having good communication skills in her relationship with her children in spite of the huge generational gap that exists between them. She ensures that her children are able to talk freely with her on issues of concern to them. As a result of the knowledge and technological advancement of her children's generation, they get to know a lot about certain things early in life. The things that Kabria's children say during their interactions sound mature and surprising to her. However, she finds a good way of relating with them. For instance, when she discovers a PPAG Pamphlet about sexual reproductive health in the possession of Obea, she put it into thought about a good way of coming out with a solution that will make her daughter come out confidently and believe in her (Kabria) and not live within herself, as in confide in her and not hide things from her.

The exercise book with its PPAG pamphlets replaced Fofo and everything to do with her in Kabria's mind when she set off after work to pick up the children from school. She knew she was going to have to ask Obea some uncomfortable questions. Not only that. She also needed to brace herself for, maybe, some uncomfortable answers too. So alone inside creamy and in the secrecy of her head, she began to practice how she would approach it. 'Obea, I am your mother so don't feel shy about...' No! Too flat. 
Obea, I know you have reached the age where you and I should been talking very often about...' Too long, too round about. Why go in circles when she could hit the nail right on the head. 'Obea, tell me. What do you make of all the talk about AIDS and STDS and teenage pregnancy? Don' $t$ you think it can start with...

'Jeez! Kabria! That is pathetic!' She chided herself 'No! No! No! No!No! Why jump to conclusion and think the worst of your daughter?

Okay, another try: ' Obea, when I came to call you this morning I noticed you push something under your pillow. Later, I snooped and found an exercise book with PPAG pamphlets. Would you want us to talk about it...? p. 72 .

Something that is able to replace everything on one's mind could be a very huge problem. However Kabria could solve effectively through how she adopts a good communication channel to know her daughter's issues in order to properly help her. She could do this because of how she puts her brain into thought and this is a mark of an educated woman. A lot of punctuation marks are used in this quotation which signifies the process of her mind. She looks for an effective way of cohabiting with everybody including her children who might be seen as kids by some other parents and due to that their views may not even be welcomed but Kabria ignores their age gap and accommodates her children's talk of " Lord Kenya" even though she has no clue of what or who or what that refers to but listens to her children and realizes that "Lord Kenya" is a popular hip-life musician in Ghana. Even though the music that Kabria is accustomed to is that of the Beatles and the Rolling Stone, she tries to get on well with her children's liking for hip-hop music. The wide generational gap between Kabria and her children does not negatively affect her relationship with her children. This is the new way of parenting that the narrator here appears to be in favor of. In view of this endorsement Kabria finds it necessary to help Fofo, a street girl who a lot of people disapprove of their involvement with her because of how streetism must have destroyed her to the level of not being able to even undergo rehabilitation. Meanwhile, Kabria's contribution to Fofo's life shows that when women are empowered they can help in mending the tattered social fiber as well as help in nation building. Through MUTE, Kabria and the other educated women; Vicky, Dina and Aggie are able to give Fofo a better and brighter future and also get to the bottom of the murder of Baby T. Kabria and the other members of MUTE are able to go into areas where national institutions hardly go to provide solution to pertinent or pressing national issues. An instance is captured in how Kabria could think about an idea of who murdered Fofo even when she was in the kitchen. She:

"Released Obea's ear absentmindedly and stared thoughtfully into the space.

"Mum, is something wrong? Obea asked, concerned.

Go and get me Auntie Dina on the telephone. Hurry! Kabria responded.

She proceeded to the kitchen while Obea made the call.

Mum, I have her! Obea called out.

Kabria told Abena as she rushed to the telephone, "Tell me when you have finished grinding the garden eggs."

She took the receiver from Obea. Dina, listen to this. Don't interrupt me. Is Fofo there with you?...Good! The hand prints on both Fofo and Baby T's face they were on their right cheeks, no?...Good!... Now listen. Call Fofo, ... yes, let her come and stand before you...Are you facing each other?...Now imitate a slap... No! No! Don't slap her, Gosh! Dina! Just imitate...You have?...Now let me task 
your imagination. Take it that you did actually slap Fofo. Take it that you were so vicious it left your palm prints on her cheeks. Which cheek would the palm print be on? ...Correct! The left cheek. So do you get where I am heading?...You don't... Get this! You naturally landed your right palm on her left cheek. No?...You still don't get it?... Oh Dina! See! You struck out with your right hand to her left cheek, didn't you?... Good! Now ask Fofo if Poison is left-handed...Bingo!

It is the educated mind that can be used this way. Though she was working in the kitchen her mind is also put into use at another important aspect of life at the same time. This form of empowerment is achieved through education.

\section{Conclusion}

The roles played by Naa Yomo and Kabria explains how bold and proactive a woman could be when she is assertive. Essentially, we realize from the discussion that an illiterate woman can be assertive. Naa Yomo who is not explained anywhere in the text to have gone through formal education has some qualities that liberate her. Through the narrative techniques surrounding the events that highlight the assertive woman, the reader is offered some hope by these strong and jubilant characters who provide us with a workable alternative to the frustrations and illusions that characterize the life of women who are expected to play multirole.

\section{References}

[1]. Abbey, Tweneboah, K, et al., Integerated Science for Senior High Schools, Unimax Macmillan Ltd., 2008

[2]. Achebe, Chinua., Things Fall Apart London: Heinemann Educational Books Ltd (1958)

[3]. Adeche Chimamanda N, "Heart is Where The Home Was" OK Nigerian Magazine, Vol. 54, No. 3, May 2003. P 4

[4]. Aegerter, Laurence, P. Southern Africa, Womanism and Post coloniality: A dialectical approach In. Gover, J. Conteh-Morgan, \& J Bryce (Eds.), The post-colonial condition of African Literature, Africa World Press, Inc., 2000, pp. 6774. Trenton, NJ.
[5]. Allan, Tuziline J. Feminist Aesthetics: "A Comparative Review About Us." Anglisticum journal IJLIS vol.4, no.10, p 43 October 1993.

[6]. Allan \& Donna Goerz A Pre-Marriage councelling HandBook, Princeton: Princeton University PRESS, 2007, PP 221-225

[7]. Alice Walker, The Colour Purple, Harcourt,1982, Brace, Jovanovich

[8]. Ama Atta Aiddoo, Anowa, Feminist Press,1993, New York.

[9]. Amma, Darko, Faceless, Sub-Saharan Publishers, 2013,Accra.

[10]. Andre, Kabore: "The symbolic use of palm, figurines and hibiscus in Adichie's Purple

[11]. Hibiscus." Linguistics and Literaray Studies vol.3, no.1, pp 32-36.Print, 2013) 117

[12]. Arnold, Anderson. Sheila Ruth and Patricia, Hopkins. The feminist face of God: The unfolding of the sacred in women, Bantam Books 1991, New York,

[13]. Arndt, Susan. "African gender trouble and African womanism: An interview with Chikwenye Ogunyemi and Wanjira Muthoni." Signs, vol.25,no.3, 2000 pp,709-726.

[14]. Ba Mariama, Scarlet Song, Longman,1995, Harlow

[15]. Badoe, Yaba. The rival. In A. A. Aidoo (Ed.), African love stories: An anthology Ayebis Clarke Publisher, 2006, pp. 76-84, Oxfordshire, UK.

[16]. Baker, Maureen., \& Elizabeth, Vivienne. Tying the knot: The impact of formalization after long term cohabitation. Journal of Family Studies,vol. 19, no.3, 2013,pp, 254-266.

[17]. Baldick, Chris. The Oxford dictionary of literary terms, Oxford University Press, 2008, Oxford, UK.

[18]. Barthel, Daine L,.The Rise of a Female Professional Ellite: The Case of Senegal." African Studies Review, vol.13, no. 3, 1985, pp 1-7

[19]. Burger Iris and White Francis E. Women In SubSaharan Africa: "Restoring Women to History" Indiana University Press, 1999, Indiana, USA.

[20]. Bessie, Head. The Cardinals, Heinemann Africa, 1993, Harlow.

[21]. Buchi, Emecheta.The Joys of Motherhood, Allison \& Busby, 1977, Nigeria.

[22]. Buchi, Emecheta. Destination Biafra, Williams Collins Sons \& Co. Ltd., 1982, Glasgow

[23]. Chimamanda' Adichie, Ngozi. Purple Hibuiscus, Lagos, Kachifo Limited, 2006,Unwin.

[24]. Collins, Patricia, H. "What's in a name? Womanism: black feminism, and beyond." The Black Scholar, vol. 26, no.1, 2001, pp 9-17. 118

[25]. Cuddon, John A. A dictionary of literary terms and literary theory (3rd ed.). Blackwell, 1991,Oxford, UK. 
[26]. D'Almeida, Irene. Research in African litearatures: Destroying the emptiness of silence, University of Florida Press, 1994.

[27]. Gainsville, Deininger, Karl. "Does Cost of Schooling Affect Enrollment by the Poor?" Universal primary education in Uganda. Economics of Education Review, vol. 22, no. 3, 2003, pp. 291-305.

[28]. Dierks, Beatrice. "The UN Fourth World Conference on Women." NWSA Journal, vol. 8, no. 2 ,

[29]. Department of Public Information, 1996, pp. 212222. New York.

[30]. Dove, Nah. "African womanism" An Afrocentric theory. Journal of Black Studies, vol.28, no.5, 1998 pp515-539. Retrieved from:http://www.jstor.org/stable/2784792.

[31]. Flora Nwapa.Efuru,Pearson Educational limited, 1966, United states of America.

[32]. Fubaya. Angela, M. "Figures of Pedagogy in Ama Atta Aiddo's Changes and Emeche Buchi's Double yoke." 2014, River State.

[33]. Gadzekpo, Seth, K., History of African Civilization ., Danmof Printing Works Limited. 2002, Accra,Ghana.

[34]. Gervais, Coleman: On their own and in their own words: Bolivian adolescent girls' empowerment through non-governmental human rights education. Journal of Youth Studies, vol.14, no.2, pp, 23-61, 2011.

[35]. Harry, Buroud: The making of masculinities: The New York men's studies, Allen and Unwin, 1987, Boston.

[36]. Kimou Stephanie, African Men Don't Do Feminists, Voices of Africa, George Town University 2013.Washington, D. C. 119

[37]. Lopez, Clarox. Women's Empowerment: Measuring The Global Gender Gap, Cologny/Geneva, 2005, Switzeland. Fapohunda, Tinuke. M. "Empowering Women And Girls Through

[38]. Higher Education in Nigeria" European Journal Of Humanities. Vol.9, no 1, p3922011.

[39]. Mariama, Ba. So Long a Letter, Heinemann,1979,Harlow, UK.

[40]. Masule, Christopher M. A comparative analysis of the depiction of women in Sifiso Nyathi's God of women: "William Shakespeare's Othello" (Published Master's thesis). Windhoek, 2014, University of Namibia.

[41]. Maxwell, Coetzee, J., Waiting for the Barbarians, Secker \& Warburg South Africa,1948 Cape Town.

[42]. Mary, Arnot. "The complex gendering of invisible pedagogies: Social reproduction or Empowerment." British Journal of Sociology of Education, vol. 23,no. 4, 2002, pp, 211217 ,
[43]. Mezu, Rose. "Introduction: A Continuum of Black Women's Activism." History of Africana Women's Literature, Black Academy Press, 2003, pp9-23.

[44]. Neshani Andreas, Purple Violet of Oshantu, Heinemann, 2003, Namibia, Windhoek.

[45]. Ndiaye, Ibrahim. Space, Time and Empowerment, edited by T. Olaniyan \& A. Quayson Blackwell Publishing Ltd. 9 May 2011, Oxford.

[46]. Nidhi Shani et al Simplified English For Primary Schools: Pupils' Book 2, Vestel Publications Ltd,2012,pp64-66, Tema.

[47]. Nwapa, Flora. One is Enough, Newman Publications, 1981 Lagos. 120

[48]. Ogunyemi, Chikwenye. O "Womanism: The dynamics of the contemporary black female novel in English."Signs, vol.11, no.1, 1985 pp63 80.Retrievedfrom:http://www.jstor.org/stable/317 4287.

[49]. Ogundipe-Leslie, M.. Stiwanism: Feminism in an African context. In T. Olaniyan\& A. Quayson (Eds.), African literature: An anthology of criticism and theory. Oxford, UK: Blac, 2007,pp 542-550

[50]. Peter Sarpong, Ghana In Retrospect: Some Aspects of Ghanaian Culture. Ghana Publishing Corporation, 1974, Accra, Tema.

[51]. Philip Teg-NefaahTabong and Philip Baba Adongo, "Infertility and childlessness: a qualitative study of the experience of infertile couples in Northern Ghana, Licencee Biomed Central Ltd, vol.9, no.2, p72, 21 March 2013.

[52]. Rose,Mezu. A history of Africana womens literature, Black Academy Press, 1993, Baltimore.

[53]. Riyani, Al. "Research on Women's Sexuality In Islam." Jurnal UIN SGD, vol.1, no. 2, 12 May 2004, pp, 1-18.

[54]. Rhode, Aletta C. The Subaltern speaks: Agency in Neshani Andreas' The purple violet of Oshaantu (Published Master's thesis), 2003, Pretoria, University of South Africa.

[55]. Sako, Rebecca. "Women Empowerment \&Advancement" Manual, Kaduna: League For Democratic Women, International journal of Business and Social Science, vol.5, no10 (1) Sep. 2014, p 159. 121

[56]. Sheila, Ruth: Issues in feminism: "An Introduction To Women's Studies", Mayfield. Publishing Company, 1997, California, USA.

[57]. Stringer, Susan O. The Senegalese Novel by Women: "Through Their Own Eyes." Peter Lang, 1996, New York.

[58]. Sirca, Roopali. The Twice Colonised: "Women in African Literature." Creative Books 1995, New Delhi, India.

[59]. Tsitsi, Dangaremga. Nervous condition, Women's Press, 1988, United Kingdom. 
[60]. Tsitsi, Dangarembga.The Book Of Not, Ayebia Clarke, Oxfordshire, 2006 U. K.

[61]. Umeh, Marie. (1995). Finale: Signifying the griottes: Flora Nwapa's legacy of $(\mathrm{Re})$ vision and voice. Research in African Literatures, vol.26, no.2, pp144-123.

[62]. Walker, Alice. In Search of Our Mother's Garden: Womanist Prose, Harcourt, Brace, Joharnovick, 1983.

[63]. Wolf, Virginia, A room of one's own, Routledge and Kegan Paul 1928 London, Boston.

[64]. Wolstoncraft, Mary. A Vindication of The Rights of Women: With Strictures on political and Moral Subjects. Printed for J. Johnson; Classmark: 305.42 WOL, 1792, London.

[65]. Zaynab, Alkali.The still born, Dearborn Financial Publishing Limited, 1984, London. 